\title{
The effect of condensed tannins in Lotus pedunculatus on the digestion and metabolism of methionine, cystine and inorganic sulphur in sheep
}

\author{
BY W. C. McNABB', G. C. WAGHORN ${ }^{2}$, T. N. BARRY ${ }^{1 *}$ AND I. D. SHELTON ${ }^{2}$ \\ ${ }^{1}$ Department of Animal Science, Massey University, Palmerston North, New Zealand \\ ${ }^{2}$ AgResearch Grasslands, Palmerston North, New Zealand
}

(Received 14 February 1992 - Accepted 17 November 1992)

\begin{abstract}
Two experiments were conducted with sheep fed on fresh Lotus pedunculatus containing $50-55 \mathrm{~g}$ condensed tannin (CT)/kg dry matter. Effects of CT were assessed by comparing control sheep (CT operating) with sheep receiving a continuous intraruminal infusion of polyethylene glycol (PEG) to bind and inactivate CT. Digestion of methionine and cystine was determined using a continuous intraruminal infusion of indigestible markers, whilst plasma irreversible loss (IRL) of methionine, cystine and inorganic sulphate was determined using ${ }^{35} \mathrm{~S}$ labelling. The proportion of microbial non- $\mathrm{NH}_{3}-\mathrm{N}$ (NAN) in whole rumen digesta NAN and the IRL of reducible $S$ from the rumen were determined using a continuous intraruminal infusion of $\left(\mathrm{NH}_{4}\right)_{2}{ }^{35} \mathrm{SO}_{4}$. The proportion of microbial $\mathrm{NAN}$ in whole rumen digesta NAN (0.44 v. 0.71) and the IRL of reducible $S$ from the rumen $(0.84 \mathrm{v} .2 .49 \mathrm{~g} \mathrm{~S} / \mathrm{d})$ were lower in control than PEG sheep. PEG sheep lost $30 \%$ of ingested methionine and cystine across the rumen, whereas the control sheep lost no methionine and cystine across the rumen. Apparent absorption of methionine from the small intestine was $27 \%$ higher in control than PEG sheep, but both groups had a similar apparent absorption of cystine. The apparent digestibility of cystine in the small intestine was lower in control $(0.42)$ than PEG (0.53) sheep, whereas the apparent digestibility of methionine was similar (0.78) for both groups. CT had no effect on plasma methionine IRL, but markedly increased the IRL of cystine $(39.8 v .22 .4 \mu \mathrm{mol} / \mathrm{min})$ and reduced the IRL of plasma inorganic sulphate (35.9 $v .50 .2 \mu \mathrm{mol} / \mathrm{min})$. A three-pool model comparing interconversions between the three plasma metabolites showed that $\mathrm{CT}$ increased the flow of cystine to body synthetic reactions (36.5 v. 17.3 $\mu \mathrm{mol} / \mathrm{min}$ ). This was due to trans-sulphuration of methionine to cystine being greater in control than in PEG sheep, whilst the oxidation of both methionine and cystine were reduced in control sheep. It was concluded that $C T$ reduced the proteolysis of forage protein and the degradation of $S$ amino acids to inorganic sulphide in the rumen, resulting in increased net absorption of methionine and increased utilization of cystine for body synthetic reactions in sheep with a high capacity for wool growth (and, hence, high cystine requirement).
\end{abstract}

Condensed tannins: Methionine: Cystine: Inorganic sulphate: Sheep

In ruminants fed on fresh forage diets there is substantial degradation of feed protein to $\mathrm{NH}_{3}$ in the rumen, some of which is incorporated into microbial protein. The rapid release of $\mathrm{NH}_{3}$ often exceeds the rate at which $\mathrm{NH}_{3}$ is incorporated into microbial protein, resulting in $20-35 \%$ of feed $\mathrm{N}$ being lost as $\mathrm{NH}_{3}$ absorbed from the rumen (MacRae \& Ulyatt, 1974; Beever \& Siddons, 1986).

In ruminants fed on fresh forage diets, abomasal infusions of protein and dietary supplementation with protein protected from ruminal degradation have stimulated wool growth (Reis \& Schinkel, 1963; Ferguson et al. 1967), milk production (Stobbs et al. 1977; 
Flores et al. 1979; Rogers et al. 1979) and live-weight gain (Barry, 1981). In particular, post-ruminal supplementation with $S$ amino acids (SAA) has markedly increased wool growth (Reis, 1979). These finding imply a deficiency of essential AA (EAA) in relation to metabolizable energy (ME) in ruminants fed on forage diets.

When fresh forages containing condensed tannins (CT) are fed to sheep a higher proportion of non- $\mathrm{NH}_{3}-\mathrm{N}$ (NAN) reaches the small intestine than with similar forages without CT (Waghorn et al. 1989). CT occur in a restricted range of forage legumes, are generally absent from grasses used in temperate agriculture (Barry, 1989) and bind to plant proteins in the rumen, reducing their degradation to $\mathrm{NH}_{3}$ (Waghorn et al. 1987b). The protein-CT complex dissociates below pH 3.5 (Jones \& Mangan, 1977) enabling enzymic digestion and absorption of AA to occur in the intestine. Waghorn et al. (1987b) reported that in sheep fed on Lotus corniculatus the presence of CT $(22 \mathrm{~g} / \mathrm{kg}$ dry matter (DM)) increased the apparent absorption from the small intestine of EAA by $62 \%$, whilst the apparent absorption of non-essential amino acids (NEAA) was decreased by $10 \%$. Thus, CT may provide a practical means by which the absorption of EAA from the small intestine can be increased in ruminants grazing fresh forages.

However, the effects of dietary CT on the degradation of SAA to sulphide in the rumen, the absorption of cystine and methionine from the small intestine of sheep and plasma kinetics of inorganic sulphate, methionine and cystine have not been measured. Objectives of the present study were to determine in sheep the effects of CT in Lotus pedunculatus on the digestion of methionine and cystine, the rate of production of reducible-S in the rumen (here defined as the irreversible loss rate; IRL) and on the plasma IRL and interconversions of methionine, cystine and inorganic sulphate.

\section{MATERIALS AND METHODS}

\section{Experimental design}

Two experiments were conducted with sheep fed on the CT-containing legume Lotus pedunculatus (cv. Grasslands 'Maku'). In Expt 1 a the IRL and transfer quotients (TQ) for methionine, cystine and inorganic sulphate were determined using intravenous infusions of ${ }^{35}$ S-labelled methionine, cysteine and inorganic sulphate commencing on day 14 of the Lotus pedunculatus feeding period. In Expt $1 \mathrm{~b}$ the sites of methionine and cystine digestion were determined using digesta fluxes calculated from an intraruminal infusion of two indigestible markers (Cr-EDTA and ruthenium phenanthroline). In Expt 2 the proportion of microbial NAN in whole rumen digesta NAN and the IRL of reducible-S from the rumen were determined from an intraruminal infusion of $\left(\mathrm{NH}_{4}\right)_{2}{ }^{35} \mathrm{SO}_{4}$. Most inorganic sulphate (about $98 \%$ ) entering the rumen is reduced to sulphide, with sulphide being the intermediate for most rumen inorganic S transactions (Kennedy \& Milligan, 1978). Therefore, the IRL of reducible $S$ represents the IRL of sulphide from the rumen.

In both experiments one group of sheep (PEG sheep) received an intraruminal infusion of polyethylene glycol (PEG) whilst the remaining group of sheep (control sheep) received an intraruminal infusion of water. PEG (molecular weight (MW) 3500) preferentially binds with CT, preventing CT reacting with protein (Jones \& Mangan, 1977; Barry \& Manley, 1986). Therefore, comparing control sheep with PEG sheep provides a means of quantifying the effects of CT on rumen digestion and intermediary metabolism.

\section{Feed}

In both experiments Lotus pedunculatus was harvested daily at 08.00 hours from a vegetative stand (300-400 $\mathrm{mm}$ high), with a sickle-bar mower. Immediately after harvest it was further cut into $50 \mathrm{~mm}$ lengths with a chaff cutter to facilitate hourly feeding. One-third 
of the daily allowance was placed on belt feeders by 10.00 hours, and the remaining twothirds stored at $4^{\circ}$ until 16.00 hours when it was then placed on belt feeders, to facilitate hourly feeding.

Expt 1. The Lotus pedunculatus (g/kg DM; S 2.97, N 38.6, CT 55) was grown at Aorangi Research Station, AgResearch Grasslands, Manawatu in medium-high fertility soil; it was fed for a total of $32 \mathrm{~d}$, commencing about 1 month after surgery, and was offered ad lib. for the first $7 \mathrm{~d}$, thereafter it was fed at a daily allowance of about $1400 \mathrm{~g} \mathrm{DM} /$ sheep per $\mathrm{d}$.

Expt 2. The Lotus pedunculatus (g/kg DM; N 34.0, CT 50) was grown at AgResearch Grasslands, Palmerston North in medium-high fertility soil; it was fed for a total of $27 \mathrm{~d}$, commencing on day 8, at a daily allowance of about $900 \mathrm{~g} \mathrm{DM} /$ sheep per $\mathrm{d}$.

\section{Animals}

Castrated male sheep were used in both experiments and were housed indoors in metabolism crates. Water was not provided but salt-lick (Dominion Salt (NZ) Ltd) was freely available. All sheep were drenched with anthelmintic to control internal parasites (12 ml Ivomec; Merck Sharp and Dohme (NZ) Ltd) and treated for lice (10 ml Wipeout; Coopers Animal Health (NZ) Ltd) before the experimental period.

Thirteen 15-month-old Romney sheep, mean live weight 43.9 (SE 0.80 ) kg, fitted with rumen ( $55 \mathrm{~mm}$ i.d.) and abomasal $(10 \mathrm{~mm}$ i.d.) cannulas about 1 month before commencing the experiment, were used in Expt 1. A separate group of fourteen 30-month-old Romney sheep, mean live weight $55 \cdot 0$ (SE 0.56$) \mathrm{kg}$, with a rumen cannula $(95 \mathrm{~mm}$ i.d.) were used in Expt 2.

In Expt 1 PEG (MW 3500; Union Carbide, Danbury, CT, USA) was continuously infused into the rumen of six sheep at a rate of $100 \mathrm{~g} / \mathrm{d}$ (in $330 \mathrm{ml}$ water) from day 6 until slaughter at day 31 or 32, whilst in Expt 2 PEG (MW 3500; $100 \mathrm{~g} / \mathrm{d}$ in $300 \mathrm{ml}$ water) was continuously infused into the rumen of seven sheep from day 15 until day 35 . All sheep were fitted with catheters in both jugular veins in Expt 1 a.

\section{Infusates and infusion}

Expt I a. Plasma IRL and TQ. All radiochemicals were obtained from Amersham (UK) Pty Ltd. $\left.{ }^{35} \mathrm{~S}\right]$ methionine $(77.8 \mathrm{mCi} / \mathrm{mmol})$ was added to sterile saline $(9 \mathrm{~g} \mathrm{NaCl} / 1)$ containing $0.25 \mathrm{mmol}$ inert L-methionine (BDH, Poole, Dorset)/1 as a carrier; $\left[{ }^{35} \mathrm{~S}\right]$ cysteine $(51.4 \mathrm{mCi} / \mathrm{mmol})$ was added to sterile saline containing $0.24 \mathrm{mmol}$ inert $\mathrm{L}$-cysteine $(\mathrm{BDH}) / 1$ as a carrier and $\left(\mathrm{NH}_{4}\right)_{2}{ }^{35} \mathrm{SO}_{4}(10 \cdot 0 \mathrm{mCi} / \mathrm{mmol})$ was added to sterile saline containing $0.31 \mathrm{mmol}$ inert ammonium sulphate $(\mathrm{BDH}) / 1$ as a carrier. The rates at which methionine, cysteine and inorganic sulphate were infused into each sheep were $7 \cdot 40,11 \cdot 04$ and $11.78 \mu \mathrm{Ci} / \mathrm{h}$ respectively.

Each isotope was infused for $30 \mathrm{~h}$, commencing with methionine (day 14), followed by cysteine (day 17) and then sulphate (day 20). Blood was sampled from the opposite jugular catheter before infusion, and at 22, 24, 26, 28 and $30 \mathrm{~h}$ infusion of each isotope. These long infusion periods were needed to ensure attainment of plateau specific activity (SA) of inorganic sulphate $(24 \mathrm{~h})$, both during the sulphate infusion and in calculating sulphate produced from oxidation of methionine and cystine (Kennedy et al. 1975). However, it is realized that such long infusions may allow some re-cycling of label from protein degradation, which may have caused an underestimation of IRL.

Expt $1 \mathrm{~b}$. Digestion of methionine and cystine. Digesta flow through the abomasum and ileum was measured using a double (solid and liquid phase) marker system. The liquid marker was ${ }^{51} \mathrm{CrEDTA}$ prepared according to the method described by Binnerts et al. (1968). The solid phase marker was Tris $\left(1,10\right.$-phenanthroline) ${ }^{103} \mathrm{RuCl}_{2}\left({ }^{103} \mathrm{Ru}\right.$ phenanthroline) prepared according to the method described by Tan et al. (1971). Sheep 
received a continuous intraruminal infusion $(230 \mathrm{ml} / \mathrm{d})$ containing $50 \mu \mathrm{Ci}{ }^{51} \mathrm{CrEDTA}$ and $42 \mathrm{mg} \mathrm{CrEDTA}$ and $9 \mu \mathrm{Ci}{ }^{103} \mathrm{Ru}$ phenanthroline and $1.4 \mathrm{mg} \mathrm{Ru}$ from day 24 until slaughter on day 31 or 32 . Death was ensured by giving a large intravenous dose of pentobarbitone. Digesta flow was calculated using the equations of Faichney (1975).

Expt 2. An intraruminal infusion of $\left(\mathrm{NH}_{4}\right)_{2}{ }^{35} \mathrm{SO}_{4}$ was used to determine the IRL of reducible $\mathrm{S}$ from the rumen, using the method of Kennedy et al. (1975), and the proportion of microbial NAN in whole rumen digesta NAN, using the method of Mathers \& Miller (1980). The $\left(\mathrm{NH}_{4}\right)_{2}{ }^{35} \mathrm{SO}_{4}(25 \mathrm{mCi}, 25-40 \mathrm{Ci} / \mathrm{mg}$; Amersham (UK) Pty Ltd) was infused at $0.2 \mathrm{mCi} / \mathrm{d}$ (in $230 \mathrm{ml}$ containing $0.5 \mathrm{~g}$ inert $\mathrm{Na}_{2} \mathrm{SO}_{4}$ ) from day 28-35. It was assumed that plateau SA of reducible $\mathrm{S}$ (i.e. sulphide) would have been attained after $18 \mathrm{~h}$ infusion (Kennedy et al. 1975).

\section{Sampling procedures}

In both experiments three $20 \mathrm{ml}$ samples of strained rumen fluid were collected at 10.00 , 13.00 and 15.00 hours from each sheep before and $3 \mathrm{~d}$ after PEG infusion commenced, and were used to determine rumen $\mathrm{NH}_{3}$ concentration.

Expt la. Sulphur amino acids and inorganic sulphate. Blood $(10 \mathrm{ml})$ was collected into heparinized syringes on ice, and centrifuged at $3000 \mathrm{~g}$ for $15 \mathrm{~min}$ to obtain plasma. Methionine and cystine were determined in plasma after deproteinizing with sulphosalicylic acid, whereas sulphate was determined in plasma deproteinized with trichloroacetic acid. After centrifugation ( $3000 \mathrm{~g}$ for $15 \mathrm{~min}$ ) the deproteinized supernatant fractions were passed through a $0.45 \mu \mathrm{m}$ cellulose acetate filter (Micro Filtration Systems, USA) to remove any remaining precipitated protein and stored at $-20^{\circ}$ for analysis.

Expt $1 b$. Digesta flow was determined for both abomasal and ileal contents. Twelve samples of abomasal digesta $(50-100 \mathrm{ml})$ were collected at $08.00,10.00,12.00,14.00,16.00$, $18.00,20.00,22.00$ and 24.00 hours on day 27 and $02.00,04.00$ and 06.00 hours on day 28 . A single ileal sample was obtained within 2 min of death by gently milking the contents from the terminal 3-4 m of the ileum.

Methionine and cystine concentrations were determined in reconstituted abomasal digesta (Faichney, 1975), ileal digesta, feed, feed refusals and rumen samples collected at $10.00,13.00$ and 15.00 hours on day 27 and 28 .

Expt 2. Whole rumen digesta and rumen fluid were sampled at 10.00 and 16.00 hours on day 35 , after $7 \mathrm{~d}$ infusion. Rumen fluid was processed according to the method of Kennedy et al. (1975) to determine the IRL of reducible $S$ from the rumen. Strained rumen fluid $\left(5 \mathrm{ml}\right.$ ) was immediately treated with $\mathrm{H}_{2} \mathrm{O}_{2}$ to oxidize all inorganic $\mathrm{S}$ to sulphate. Proteins were then precipitated so that radioactivity and inorganic sulphate concentration could be determined in the supernatant fraction.

Rumen whole digesta and microbial pellet samples were processed according to the method of Mathers \& Miller (1980) to determine the proportion of microbial NAN in whole digesta NAN. Rumen whole digesta (about $200 \mathrm{~g}$ ) was stored at $-20^{\circ}$, whilst strained rumen fluid (about $100 \mathrm{ml}$ ) was centrifuged at $1000 \mathrm{~g}$ for $1 \mathrm{~min}$ to separate feed particles. The supernatant fraction was decanted into a second tube and centrifuged at $20000 \mathrm{~g}$ for $20 \mathrm{~min}$ to precipitate a microbial pellet. Radioactivity and NAN concentration were determined in rumen whole digesta and microbial pellet samples.

\section{Sample analysis}

Rumen ammonia. Rumen $\mathrm{NH}_{3}$ was determined by the method of Williams \& Twine (1967) using an AutoAnalyzer (Technicon Industrial Systems, USA).

Methionine and cystine. Freeze-dried digesta and feed samples $(10 \mathrm{mg})$ were placed in vacuum hydrolysis tubes and oxidized with performic acid $\left(5.0 \mathrm{ml}\right.$ for $16 \mathrm{~h}$ at $\left.4^{\circ}\right)$ to convert 
cystine and methionine to cysteic acid and methionine sulphone. Oxidation was stopped by the addition of $0.75 \mathrm{ml} \mathrm{HBr}(450 \mathrm{ml} / \mathrm{l})$ and the contents of the flasks were concentrated by evaporation to dryness under reduced pressure at $40-50^{\circ}$. Then $20 \mathrm{ml} 6.8 \mathrm{M}-\mathrm{HCl}$ was added to the flasks and the samples hydrolysed at $110^{\circ}$ for $22 \mathrm{~h}$. The hydrolysates were filtered through Whatman no. 1 paper and concentrated by rotary evaporation to dryness under reduced pressure at $40-50^{\circ}$. The hydrolysates were transferred to $25 \mathrm{ml}$ volumetric flasks using three $5 \mathrm{ml}$ portions of $0.2 \mathrm{M}$-sodium citrate $\mathrm{HNO}_{3}$ buffer $(0.75 \mu \mathrm{l} / \mathrm{l}$ pentachlorophenol, $\mathrm{pH} 2 \cdot 2$ ), and made up to $25 \mathrm{ml}$. Samples were then passed through $0.45 \mu \mathrm{m}$ cellulose acetate filters (Micro Filtration Systems, USA) and stored at $-20^{\circ}$.

The concentrations of methionine and cystine in $40 \mu \mathrm{l}$ deproteinized plasma and of methionine sulphone and cysteic acid in hydrolysates were determined by ion-exchange chromatography on a high-performance liquid chromatograph (Waters Associates, USA), using a $\mathrm{Na}^{+}$-form AA analysis column (Waters Associates, USA) maintained at $62^{\circ}$. AA were detected by the fluorescence of their orthophthaldehyde (OPA) derivatives formed by a post-column reaction of the column eluate with OPA using a Waters (USA) 420AC fluorescence detector ( $338 \mathrm{~nm}$ excitation and $425 \mathrm{~nm}$ emission wavelength). All solutions for use in HPLC were filtered though a $0.2 \mu \mathrm{m}$ cellulose acetate (aqueous) or polytetrafluoroethylene (non-aqueous) filter (Micro Filtration Systems, USA) and saturated with $\mathrm{O}_{2}$-free $\mathrm{N}_{2}$. S-protecting agents were not added during deproteinization, but all analyses were carried out straight after the completion of Expt 1.

The ${ }^{35} \mathrm{~S}$ radioactivity in methionine and cystine was determined in a $2 \mathrm{ml}$ portion of deproteinized plasma, in order to obtain sufficient activity in the relevant peaks. After separation by HPLC, SAA peaks were collected in $1 \mathrm{ml}$ portions into scintillation vials as they flowed from the detector and $8.0 \mathrm{ml}$ PCS II scintillation fluid (Phase Combining System II; Amersham (Australia) Pty Ltd) and $2.0 \mathrm{ml}$ glacial acetic acid were added to the samples. The acetic acid prevented phase separation and its addition resulted in the formation of a clear, stable gel. Samples were counted in a scintillation counter (Beckman LS3801, USA).

Plasma inorganic sulphate. Inorganic sulphate in deproteinized plasma was separated from organic $\mathrm{S}$ with Dowex 1-X8 resin $\left(\mathrm{Cl}^{-}\right.$-form, $18-52$ mesh size, $4.5 \mathrm{mmol}$ binding capacity $/ \mathrm{ml}$; BDH), which is a strong-base anion-exchanger capable of binding inorganic sulphate. Dowex 1-X8 contains benzyltrimethylammonium side-chains which can degrade to yield free $\mathrm{NH}_{3}$, which interferes with the colorimetric determination of sulphate. The resin was washed, therefore, before use by shaking in $1 \mathrm{M}-\mathrm{NaOH}$ for $16 \mathrm{~h}$ at room temperature to remove free $\mathrm{NH}_{3}$, followed by shaking in deionized water three times for $4 \mathrm{~h}$ at room temperature and finally regeneration of the resin by shaking in $1 \mathrm{M}-\mathrm{HCl}$ for $16 \mathrm{~h}$ at room temperature.

Deproteinized plasma $(3 \mathrm{ml})$ together with washed Dowex 1-X8 $(1 \mathrm{~g})$ and deionized water $(7 \mathrm{ml})$ were shaken for $16 \mathrm{~h}$ at room temperature. The supernatant fraction, which contained ${ }^{35} \mathrm{~S}$-labelled AA, was discarded whilst the resin, which had inorganic sulphate bound to it, was washed three times in $5 \mathrm{ml}$ deionized water to remove all residual deproteinized plasma. Inorganic sulphate was eluted off the resin by shaking the resin in $5 \mathrm{ml} 1 \mathrm{M}-\mathrm{HCl}$ for $16 \mathrm{~h}$ at room temperature, then decanted and $1 \mathrm{ml}$ was added to $10 \mathrm{ml}$ PCS II for scintillation counting. Inorganic sulphate concentration was determined by the automated method of Johnson \& Nashida (1952), using an AutoAnalyzer (Technicon Industrial Systems, USA). All standards used for autoanalysis were made up in $1 \mathrm{M}-\mathrm{HCl}$ which had been treated similarly to the deproteinized plasma samples.

The ${ }^{35} \mathrm{~S}$-labelled methionine, cysteine and sulphate infusates were treated similarly to deproteinized plasma in order to determine the recoveries of ${ }^{35} \mathrm{~S}$-labelled methionine, cysteine and sulphate for calculation of SA, IRL and TQ. 
Attainment of plateau SA. Analyses of plasma samples from one control and one PEG sheep established that plateau SA of methionine, cystine and inorganic sulphate had been attained after $24 \mathrm{~h}$ of infusion. Samples taken after 26,28 and $30 \mathrm{~h}$ were then pooled for each sheep for the determination of plasma concentration and SA of methionine, cystine and inorganic sulphate.

Reducible $S$ irreversible loss from the rumen. ${ }^{35} \mathrm{~S}$ radioactivity in the protein-free rumen supernatant fraction was determined by adding $1 \mathrm{ml}$ supernatant fraction to $10 \mathrm{ml}$ PCS II which was then counted in a scintillation counter (Beckman LS3801, USA). The concentration of inorganic sulphate was determined in protein-free rumen supernatant fraction after acidification by addition of an equal volume of $4 \mathrm{M}-\mathrm{HCl}$, using inductively coupled Ar plasma emission spectrometry (ICP-ES; Lee, 1983). These determinations rely on the well-established fact that the methionine and cystine concentration in rumen fluid is negligible (Hungate, 1966).

Proportion of microbial NAN in whole rumen digesta NAN. Freeze-dried bacteria and rumen digesta samples were oxidized with performic acid to convert inorganic $S$ to sulphate, methionine to methionine sulphone and cystine to cysteic acid, after which they were hydrolysed with $6.8 \mathrm{M}-\mathrm{HCl}$ and inorganic sulphate was removed as insoluble $\mathrm{BaSO}_{4}$ according to the method of Mathers \& Miller (1980). The radioactivity of ${ }^{35}$ S-labelled SAA in the sulphate-free supernatant fraction samples was determined by adding $1 \mathrm{ml}$ of the supernatant fraction to $10 \mathrm{ml}$ of PCS II for scintillation counting.

The total $\mathrm{N}$ and $\mathrm{NH}_{3}-\mathrm{N}$ concentration in the original whole rumen digesta samples and the total $\mathrm{N}$ concentration in sulphate-free rumen whole digesta and microbial supernatant fractions were determined by a micro-Kjeldahl procedure (Tecator Kjeltec Auto 1030 Analyser; Tecator AB, Höganäs, Sweden). It was assumed that total $\mathrm{N}$ present in microbial samples was NAN. The contribution of $\mathrm{NH}_{3}-\mathrm{N}$ to whole rumen digesta $\mathrm{N}$ was removed by multiplication of ${ }^{35} \mathrm{~S}: \mathrm{N}$ (whole rumen digesta) by $\mathrm{N}: \mathrm{NAN}$ (whole rumen digesta) to give an estimate of ${ }^{35} \mathrm{~S}: \mathrm{NAN}$ (rumen whole digesta).

\section{Calculation of data and statistical analysis}

Means are presented with their standard errors of the difference (SED) or their standard errors as appropriate. Comparison between control and PEG treatments was done by analysis of variance.

Methionine and cystine flux through the abomasum was calculated from equation 1.

$$
\text { SAA flux }(\mathrm{g} / \mathrm{d})=\text { digesta SAA concentration }(\mathrm{g} / \mathrm{g} \mathrm{DM}) \times \text { true digesta flux }(\mathrm{g} / \mathrm{d}) \text {. }
$$

IRL, measured at plateau SA, is the rate at which a metabolite leaves the primary pool and does not return within the time-course of the experiment, and was calculated from equation 2. All determinations of SA were corrected for background by subtracting values determined in samples taken at the start of each infusion.

$$
\operatorname{IRL}(\mathrm{g} \mathrm{S} / \mathrm{d})=\frac{\text { infusion rate into pool }(\text { disintegrations } / \mathrm{min}(\mathrm{dpm}) \text { per } \mathrm{d})}{\mathrm{SA} \text { of } \operatorname{pool}(\mathrm{dpm} / \mathrm{g} \mathrm{S})} \text {. }
$$

TQ, measured at plateau SA, is defined as the proportion of radioactive label detected in a secondary pool (B) which originated from an infusion into a primary pool (A), and was calculated from equation 3 :

$$
\mathrm{TQ}=\frac{\mathrm{SA} \text { of pool B }(\mathrm{dpm} / \mu \mathrm{mol})}{\mathrm{SA} \text { of pool } \mathrm{A}(\mathrm{dpm} / \mu \mathrm{mol})}
$$


The proportion of microbial NAN in whole rumen digesta NAN was calculated from equation 4 (Mathers \& Miller, 1980):

$$
\frac{{ }^{35} \mathrm{~S}: \text { NAN (digesta) }}{{ }^{35} \mathrm{~S}: \text { NAN (microbial) }}
$$

The results of Expt 1 a are presented as a three-pool compartmentalized model similar to that proposed by Nolan et al. (1976) for $\mathrm{N}$ transactions in the rumen. To calculate the various flows within the model, methionine IRL and the proportion of cystine and inorganic sulphate derived from methionine (TQ) were calculated from the $\left[{ }^{35} \mathrm{~S}\right]$ methionine infusion, with the procedure being repeated for infusions of ${ }^{35} \mathrm{~S}$-labelled cysteine and sulphate. The IRL and TQ were then used in mathematical equations proposed by Nolan et al. (1976) to solve the three-pool model. As the TQ of cystine and methionine from sulphate, and of methionine from cystine were determined to be zero within the time-course of the experiment, it was assumed, in constructing the model, that the corresponding flows were also zero.

\section{RESULTS \\ Expt 1}

Intake. The DM (1212 v. 1296 (SED 43.3) g DM/d), total S $(3.6$ v. 3.9 (SED 0.13) g S/d), methionine $(3.1 v .3 .2(\operatorname{SED} 0.10) \mathrm{g} / \mathrm{d})$ and cystine $(3.3 v .3 .5(\operatorname{SED} 0.08) \mathrm{g} / \mathrm{d})$ intakes of control (CT operating) and PEG (CT not operating) sheep respectively were not significantly different $(P>0.05)$.

Rumen $\mathrm{NH}_{3}$ concentration before PEG infusion was similar $(P>0-05)$ in control (111 (SE 2.5) $\mathrm{mg} \mathrm{NH}_{3}-\mathrm{N} / \mathrm{l}$ ) and PEG (134 (SE 3.5) $\mathrm{mg} \mathrm{NH}_{3}-\mathrm{N} / 1$ ) sheep. However, after $3 \mathrm{~d}$ of PEG infusion rumen $\mathrm{NH}_{3}$ concentration increased to 200 (SE 4.2) $\mathrm{mg} \mathrm{NH}_{3}-\mathrm{N} / 1$ $(P<0.001)$, whereas in the control sheep it remained unchanged (106 (SE 2.6) $\mathrm{mg} \mathrm{NH}_{3}-\mathrm{N} / \mathrm{l}$; $P>0.05)$.

\section{Expt $1 a$}

Methionine. The recovery from HPLC of both methionine and the $\left[{ }^{35}\right.$ S]methionine infusates added to deproteinized plasma was 0.98 (SE 0.03). Neither plasma methionine concentration nor IRL (Table 1) differed between control and PEG sheep $(P<0 \cdot 05)$. However, in control sheep methionine had a lower rate of oxidation to sulphate $(0.7 v .1 .2 \mu \mathrm{mol} / \mathrm{min} ; P<0.05$; Fig. 1) and tended to have a lower flux to productive processes and maintenance $(8.2 v .13 .6 \mu \mathrm{mol} / \mathrm{min} ; P<0 \cdot 1$; Fig. 1) than in PEG sheep.

Cystine and taurine. The recovery from HPLC of both cystine and the $\left[{ }^{35} S\right]$ cysteine infusate added to deproteinized plasma was 0.95 (SE 0.04). Both plasma cystine concentration $(P<0.001)$ and IRL $(P<0.05)$ were higher in control sheep than in PEG sheep. Fig. 1 shows that in control sheep the increased plasma IRL of cystine was associated with a $76 \%$ increase in the entry rate of cysteine $(28.1 v .16 .0 \mu \mathrm{mol} / \mathrm{min}$; $P<0.05$ ) into plasma from whole body protein turnover and absorption from the small intestine, a $79 \%$ increase in the transulphuration of methionine to cystine $(11.7 v .6 .5 \mu \mathrm{mol} / \mathrm{min} ; P<0.05)$ and a $36 \%$ decrease in the oxidation of cystine to sulphate (3.3 v. $5 \cdot 2 \mu \mathrm{mol} / \mathrm{min} ; P<0.05)$.

As a consequence of $\mathrm{CT}$, the differences in plasma cystine metabolism between control and PEG sheep resulted in a $110 \%$ increase in the cystine flux to productive processes and maintenance $(36.5 v .17 \cdot 4 \mu \mathrm{mol} / \mathrm{min}$; Fig. 1), which represents $91 \%$ of cystine flux in control sheep compared with only $74 \%$ of cystine flux in PEG sheep $(P<0.05$; Table 1$)$. Plasma taurine concentration was lower in control sheep than in PEG-infused sheep $(P<0 \cdot 05)$. 
Table 1. Expt la. The concentration ( $\mu \mathrm{mol} / \mathrm{l})$, irreversible loss $(\mu \mathrm{mol} / \mathrm{min})$ and transfer quotients of plasma sulphur amino acids and sulphate in sheep fed on Lotus pedunculatus, with and without an intraruminal infusion of polyethylene glycol (PEG), together with the proportion of total flux flowing to various processest

(Mean values with their standard errors of difference (SED) for seven control and six PEG sheep)

\begin{tabular}{|c|c|c|c|c|}
\hline & $\begin{array}{l}\text { Control } \\
\text { sheep }\end{array}$ & $\begin{array}{l}\text { PEG-infused } \\
\text { sheep }\end{array}$ & SED & $\begin{array}{l}\text { Statistical } \\
\text { significance } \\
\text { of difference }\end{array}$ \\
\hline \multicolumn{5}{|l|}{ Concentration $(\mu \mathrm{mol} / \mathrm{l})$} \\
\hline Taurine & $8 \cdot 7$ & 160 & $2 \cdot 50$ & $*$ \\
\hline Cystine & $41 \cdot 7$ & $27 \cdot 5$ & 3.80 & $* * *$ \\
\hline Methionine & $17 \cdot 5$ & $15 \cdot 4$ & $2 \cdot 50$ & NS \\
\hline Sulphate & 1981 & 1990 & $1 \cdot 10$ & NS \\
\hline \multicolumn{5}{|l|}{ Transfer quotient $\S$} \\
\hline Cystine from methionine & 0.29 & $0 \cdot 30$ & 0.04 & NS \\
\hline Sulphate from methionine & 0.02 & 0.03 & 0.01 & NS \\
\hline Sulphate from cystine & 0.09 & $0 \cdot 11$ & 0.01 & NS \\
\hline \multicolumn{5}{|l|}{ Irreversible loss $(\mu \mathrm{mol} / \mathrm{min})$} \\
\hline Methionine & $20 \cdot 6$ & $19 \cdot 9$ & $2 \cdot 95$ & NS \\
\hline Cystine & $39 \cdot 8$ & $22 \cdot 4$ & $7 \cdot 36$ & $*$ \\
\hline Sulphate & 35.9 & $50-2$ & $4 \cdot 45$ & $* *$ \\
\hline \multicolumn{5}{|l|}{ Proportion of flux transferred } \\
\hline Methionine to cystine & 0.57 & 0.31 & $0 \cdot 110$ & $*$ \\
\hline Methionine to sulphate & 0.04 & 0.06 & 0.019 & NS \\
\hline Cystine to sulphate & $0 \cdot 10$ & 0.26 & 0.053 & $*$ \\
\hline Cystine to $\mathrm{P}+\mathrm{M}$ & 0.91 & 0.74 & 0.050 & * \\
\hline Methionine to $\mathrm{P}+\mathrm{M}$ & $0 \cdot 40$ & 0.62 & $0 \cdot 110$ & + \\
\hline
\end{tabular}

NS, not significant $(P>0 \cdot 10)$

$(\mathrm{P}+\mathrm{M})$ Productive processes and maintenance.

${ }^{*} P<0.05, * * P<0.01, * * * P<0.001$.

$+P<0 \cdot 10$.

$\ddagger$ For details of procedures, see pp. 649-652.

$\$$ The transfer quotients for cystine from sulphate, methionine from sulphate and methionine from cystine are not presented, but were all zero within the time course of the experiment.

Sulphate. The recovery by Dowex 1-X8 resin of both $\mathrm{K}_{2} \mathrm{SO}_{4}$ and the ${ }^{35} \mathrm{SO}_{4}$ infusate added to deproteinized plasma was 0.70 (SE 0.05). There was no detectable recovery of either methionine or cystine and $\left[{ }^{35} \mathrm{~S}\right]$ methionine or $\left[{ }^{35} \mathrm{~S}\right]$ cysteine by Dowex 1-X8 resin. Plasma sulphate concentration, corrected for recovery, was similar in control and PEG sheep $(P>0.05$; Table 1). However, the IRL of sulphate from plasma was $40 \%$ lower in control sheep compared with PEG sheep (Table 1). This was largely due to a lower rate of cystine $(P<0.05)$ and methionine $(P<0.05)$ oxidation to sulphate, and $26 \%$ less sulphate $(P>0.05)$ entering the plasma from sources other than methionine and cystine oxidation (Fig. 1).

\section{Expt $1 b$}

The digestion of methionine and cystine in the gastrointestinal tract. The recovery $(\%)$ from HPLC of cysteic acid and methionine sulphone added to feed hydrolysate samples was 98 (SE 0.03) for cysteic acid and 97 (SE 0.04) for methionine sulphone. The intakes of methionine (2.81 and $2.95 \mathrm{~g} / \mathrm{d}$; Table 2$)$ and cystine $(3.33$ and $3.52 \mathrm{~g} / \mathrm{d}$; Table 3$)$ were similar $(P>0.05)$ for control and PEG sheep respectively. The abomasal flux of methionine $(2.75$ v. $2.09 \mathrm{~g} / \mathrm{d})$ and of cystine $(3.33$ v. $2.52 \mathrm{~g} / \mathrm{d})$ were both higher $(P<0.001)$ 


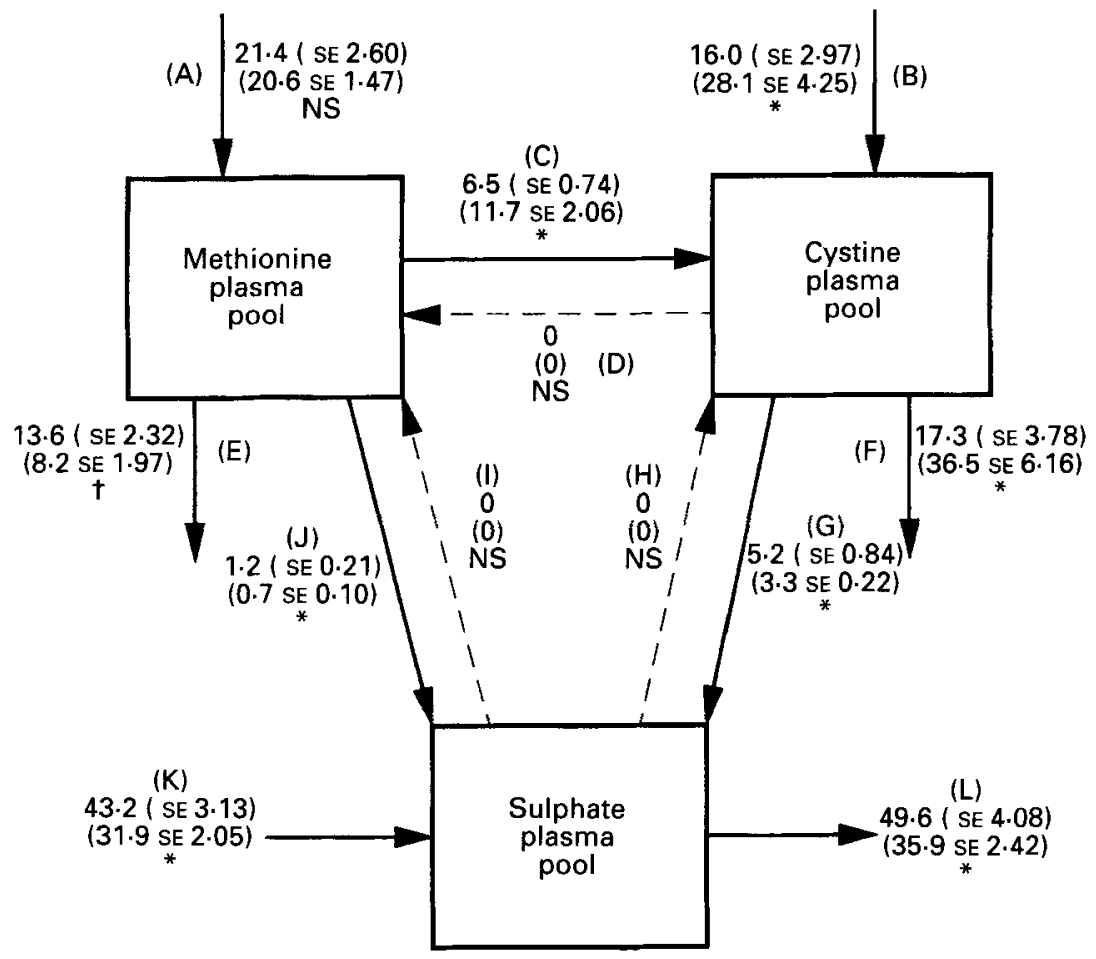

Fig. 1. A general three-pool compartmentalized model for sulphur amino acid transactions in the posthepatic plasma of sheep fed on Lotus pedunculatus, with and without an intraruminal infusion of polyethylene glycol (PEG). Mean values with their standard errors are shown for six PEG-infused sheep, with the corresponding values for seven control sheep in parentheses. Mean values for $\mathrm{PEG}$-infused sheep were significantly different from those for control sheep: $* P<0 \cdot 05, \uparrow P<0 \cdot 1$. NS, not significant. $\uparrow \uparrow$, Rates of flow $(\mu \mathrm{mol} / \mathrm{min})$ in the model which are often composite of several pathways of transfer. The pathways are: (A) methionine entering the plasma from whole-body protein turnover and absorption from the small intestine, (B) cystine entering the plasma from whole-body protein turnover and absorption from the small intestine, $(C)$ transulphuration of methionine to cystine, (D) conversion of cystine to methionine, which does not occur in mammalian tissue, (E) methionine leaving the plasma and being utilized for productive processes and maintenance, $(F)$ cystine leaving the plasma and being utilized for productive processes and maintenance, $(G)$ cystine oxidized to sulphate (and carbon dioxide), (H) plasma sulphate reassimilated as cystine. This cannot occur directly in mammalian tissue, but sulphate re-entering the rumen via saliva may be reabsorbed as cystine from microbial protein, (I) plasma sulphate reassimilated as methionine. This cannot occur directly in mammalian tissue, but sulphate re-entering the rumen via saliva may be reabsorbed as methionine from microbial protein, $(\mathrm{J})$ methionine oxidized to sulphate (and carbon dioxide), (K) sulphate entering the plasma, chiefly from oxidation of sulphide absorbed from the rumen, but also sulphate and oxidation of sulphide absorbed from the intestine and (L) sulphate leaving the plasma chiefly in urine, but also recycled directly to the intestines and rumen via saliva.

in control than in PEG sheep. There was essentially no loss of methionine or cystine across the rumen in control sheep, whilst $29 \%$ of methionine intake $(P<0.001)$ and $28 \%$ of cystine intake $(P<0.001)$ disappeared across the rumen in PEG sheep. Although the ileal flux of methionine $(0.63 v .0 .43 \mathrm{~g} / \mathrm{d})$ and of cystine $(1.93 v .1 \cdot 18 \mathrm{~g} / \mathrm{d})$ was higher $(P<0.001)$ in control than PEG sheep, the apparent absorption of methionine from the small intestine was $27 \%$ higher $(P<0.001)$ in control sheep $(2 \cdot 11 \mathrm{~g} / \mathrm{d})$ than in PEG sheep $(1.66 \mathrm{~g} / \mathrm{d})$, whereas the apparent absorption of cystine from the small intestine was similar $(P>0.05)$ for control sheep $(1.40 \mathrm{~g} / \mathrm{d})$ and PEG sheep $(1.34 \mathrm{~g} / \mathrm{d})$. The apparent digestibility of methionine in the small intestine was similar $(P>0.05)$ for control sheep $(0.77)$ and PEG sheep (0.79). In contrast, the apparent digestibility of cystine in the small intestine was lower $(P<0.01)$ in control sheep $(0.42)$ than in PEG sheep $(0.53)$. 
Table 2. Expt $1 \mathrm{~b}$. The intake and digestion of methionine by sheep fed on Lotus pedunculatus, with and without an intraruminal infusion of polyethylene glycol $(P E G) \dagger$

(Mean values with their standard errors of difference (SED) for seven control and six PEG sheep)

\begin{tabular}{|c|c|c|c|c|}
\hline Methionine & Control sheep & PEG-infused sheep & SED & $\begin{array}{c}\text { Statistical } \\
\text { significance } \\
\text { of difference }\end{array}$ \\
\hline Intake $(\mathrm{g} / \mathrm{d})$ & $2 \cdot 81$ & $2 \cdot 95$ & 0.082 & NS \\
\hline \multicolumn{5}{|l|}{ Abomasal fux: } \\
\hline $\mathrm{g} / \mathrm{d}$ & $2 \cdot 75$ & $2 \cdot 09$ & 0.063 & $* * *$ \\
\hline g/g eaten & 0.98 & 0.71 & 0.018 & $* * *$ \\
\hline \multicolumn{5}{|l|}{ Ileal flux: } \\
\hline $\mathrm{g} / \mathrm{d}$ & 0.63 & 0.43 & $0 \cdot 043$ & $* * *$ \\
\hline $\mathrm{g} / \mathrm{g}$ eaten & 0.22 & $0 \cdot 15$ & 0.016 & $* * *$ \\
\hline \multicolumn{5}{|c|}{$\begin{array}{l}\text { Apparent absorption from small } \\
\text { intestine: }\end{array}$} \\
\hline $\mathrm{g} / \mathrm{d}$ & $2 \cdot 11$ & $1 \cdot 66$ & 0.023 & $* * *$ \\
\hline $\mathrm{g} / \mathrm{d}$ eaten & 0.75 & $0 \cdot 56$ & 0.017 & $* * *$ \\
\hline $\mathrm{g} / \mathrm{g}$ entering SI & 0.77 & 0.79 & 0.011 & NS \\
\hline
\end{tabular}

NS, not significant $(P>0.05)$; SI, small intestine.

$* * * P<0.001$.

$\dagger$ For details of procedures, see pp. 649-651.

Table 3. Expt $1 b$. The intake and digestion of cystine by sheep fed on Lotus pedunculatus, with and without an intraruminal infusion of polyethylene glycol $(P E G) \dagger$

(Mean values with their standard errors of difference (SED) for seven control and six PEG sheep)

\begin{tabular}{|c|c|c|c|c|}
\hline Cystine & Control sheep & PEG-infused sheep & SED & $\begin{array}{c}\text { Statistical } \\
\text { significance } \\
\text { of difference }\end{array}$ \\
\hline \multirow{2}{*}{\multicolumn{2}{|c|}{ Abomasal flux: }} & $3 \cdot 52$ & $0 \cdot 102$ & NS \\
\hline $\mathrm{g} / \mathrm{d}$ & 3.33 & $2 \cdot 52$ & & $* * *$ \\
\hline $\mathrm{g} / \mathrm{g}$ eaten & 1.00 & 0.72 & $0 \cdot 096$ & $* * *$ \\
\hline \multicolumn{5}{|l|}{ Ileal flux: } \\
\hline $\mathrm{g} / \mathrm{d}$ & 1.93 & $1 \cdot 18$ & 0.131 & $* * *$ \\
\hline $\mathrm{g} / \mathrm{g}$ eaten & 0.58 & 0.34 & 0.032 & $* * *$ \\
\hline \multicolumn{5}{|c|}{$\begin{array}{l}\text { Apparent absorption from small } \\
\text { intestine: }\end{array}$} \\
\hline $\mathrm{g} / \mathrm{d}$ & $1 \cdot 40$ & $1 \cdot 34$ & $0 \cdot 114$ & NS \\
\hline $\mathrm{g} / \mathrm{d}$ eaten & 0.42 & $0 \cdot 38$ & 0.048 & NS \\
\hline $\mathrm{g} / \mathrm{g}$ entering SI & 0.42 & 0.53 & $0-031$ & $* *$ \\
\hline
\end{tabular}

NS, not significant $(P>0.05)$; SI, small intestine.

$* * P<0.01, * * * P<0.001$.

$\dagger$ For details of procedures, see pp. 649-651.

Expt 2

Intake. The DM intakes of control sheep $(818 \mathrm{~g} \mathrm{DM} / \mathrm{d})$ and PEG sheep (893 (SED 47.2) g DM/d) fed on fresh Lotus pedunculatus were not significantly different $(P>0.05)$. Total $\mathrm{N}$ intake was also similar $(P>0.05)$ for control sheep $(27.8 \mathrm{~g} \mathrm{~N} / \mathrm{d})$ and PEG sheep (30.4 (SED 0.30) g N/d). 
Table 4. Expt 2. The proportion of microbial non-ammonia-nitrogen (NAN) in total rumen digesta $N A N$ and the concentration and irreversible loss rate (IRL) of reducible sulphur in the rumen of sheep fed on Lotus pedunculatus, with and without an intraruminal infusion of polyethylene glycol $(P E G) \dagger$

(Mean values with their standard errors of difference (SED) for seven animals per treatment).

\begin{tabular}{lcccc}
\hline \hline & Control sheep & PEG-infused sheep & SED & $\begin{array}{c}\text { Statistical } \\
\text { significance } \\
\text { of difference }\end{array}$ \\
\hline $\begin{array}{l}\text { Proportion microbial } \\
\text { NAN in digesta NAN }\end{array}$ & 0.44 & 0.71 & 0.052 & $* * *$ \\
$\begin{array}{l}\text { Rumen-reducible S: } \\
\text { Concentration (mg S/l) }\end{array}$ & 26.8 & 31.1 & 3.10 & NS \\
IRL (g S/d) & 0.84 & 2.49 & 0.261 & $* * *$ \\
\hline
\end{tabular}

NS, not significant $(P>0.05)$.

*** $P<0.001$.

$\dagger$ For details of procedures, see pp. 650-652.

Rumen ammonia concentration. Rumen $\mathrm{NH}_{3}$ concentration before $\mathrm{PEG}$ infusion was higher $(P<0.05)$ in the control sheep $\left(186\left(\mathrm{SE} \mathrm{4.6)} \mathrm{mg} \mathrm{NH}_{3}-\mathrm{N} / 1\right)\right.$ than in the PEG sheep (152 (SE 4.2) mg $\mathrm{NH}_{3}-\mathrm{N} / 1$ ). However, after $3 \mathrm{~d}$ of $\mathrm{PEG}$ infusion rumen $\mathrm{NH}_{3}$ concentration increased to 398 (SE 7.3) $\mathrm{mg} \mathrm{NH}_{3}-\mathrm{N} / 1(P<0 \cdot 001)$, whereas in the control group it remained unchanged (204 (SE 6.8) $\mathrm{mg} \mathrm{NH}_{3}-\mathrm{N} / 1 ; P>0.05$ ).

Rumen reducible sulphur irreversible loss. The concentration of reducible $\mathrm{S}$ in rumen fluid was similar $(P>0.05)$ for control and PEG sheep (Table 4). However, the IRL of reducible $\mathrm{S}$ from the rumen, which represents inorganic $\mathrm{S}$ absorbed from the rumen as sulphide, sulphide flowing to the abomasum and sulphide converted to bacterial SAA, was considerably lower $(P<0.001)$ in control than PEG sheep.

Rumen NAN concentrations. The concentration of total NAN in rumen whole digesta was higher $(P<0.001)$ in control sheep $(18.9 \mathrm{mg} / \mathrm{g} \mathrm{DM})$ than PEG sheep $(12.3$ (SED 0.76) $\mathrm{mg} / \mathrm{g} \mathrm{DM} ; P<0.001$ ). The proportion of microbial NAN in rumen whole digesta NAN was lower $(P<0 \cdot 001)$ in control than PEG sheep (Table 4).

\section{DISCUSSION}

PEG displaces CT from CT-protein complexes (Jones \& Mangan, 1977) and completely binds available CT (Barry \& Forss, 1983). Consequently, when PEG binds CT in the rumen, preventing it from binding to protein, plant protein can be degraded to rumen $\mathrm{NH}_{3}$. Therefore, the increase in rumen $\mathrm{NH}_{3}$ concentration after $3 \mathrm{~d}$ of intraruminal PEG infusion indicates that in the present study PEG infusions effectively rendered $\mathrm{CT}$ unreactive in the rumen in both experiments. The lower proportion of microbial NAN in whole rumen digesta NAN in control sheep suggests that CT either reduced microbial protein synthesis or reduced the degradation of plant NAN.

The negligible net losses of methionine and cystine across the rumen of control sheep in Expt 1 compared with the net losses of $28-29 \%$ from PEG sheep suggests there was a reduction in the degradation of plant NAN in the presence of CT. Losses of $25-35 \%$ of $\mathrm{N}$ intake from the rumen of sheep fed on fresh grasses and clovers have been reported by MacRae \& Ulyatt (1974). However, the effect of CT on microbial NAN synthesis is less 
clear. A Lotus corniculatus cultivar containing $32 \mathrm{~g} \mathrm{CT} / \mathrm{kg}$ DM resulted in a significantly $(P<0.05)$ lower flow of microbial NAN to the duodenum compared with a cultivar with only $4.6 \mathrm{~g} \mathrm{CT} / \mathrm{kg} \mathrm{DM}$, when fed to sheep (Waghorn et al. 1987a). It is clear that CT reduced the degradation of plant proteins in the rumen and increased the flux of SAA to the intestine, but the effects of CT on microbial growth are not fully understood.

The rumen reducible S IRL measured in the present study represents inorganic sulphide production in the rumen and is indicative of proteolysis and degradation of SAA from plant proteins. Plant proteins were probably the principal source of total $\mathrm{S}$ entering the rumen (Kennedy \& Milligan, 1978) in sheep fed on Lotus pedunculatus (2.97 g S/kg DM). Inorganic sulphate in saliva generally provides a lesser contribution (Kennedy et al. 1975). $S$ passing to the abomasum is virtually all in an organic form (Kennedy \& Milligan, 1978), whereas sulphide is absorbed across the rumen epithelium. The IRL of reducible $S$ from control and PEG sheep $(0.84$ v. $2.49 \mathrm{~g} \mathrm{~S} / \mathrm{d}$ respectively) are equivalent to 35 and $93 \%$ of the daily intake of feed $S$ by sheep in Expt 2 . This suggests a much lower degradation of plant and salivary $S$ in control sheep and supports observations of minimal methionine and cystine loss from the rumen.

The most significant finding from the digestion experiments was that CT resulted in a significantly greater flux of SAA to the intestine compared with that of PEG sheep. However, there was only an increased absorption of methionine and not cystine from the small intestine. Differences in amino acid absorption depend on the relative flows through the duodenum of undegraded protein, microbial protein and endogenous protein, together with their AA composition and the apparent absorption of each AA. A reduction in apparent digestibility of cysteine has been reported with formaldehyde treatment of casein (Ashes et al. 1984) and was attributed to an increased binding between cysteine and formaldehyde. Therefore, a similar type of interaction may have occurred between cysteine and CT, but not methionine and CT, in the present study. In an experiment where Lotus corniculatus (22 g CT/kg DM) was fed to sheep with and without PEG, CT reduced the apparent digestibility of asparagine, serine, glutamate, proline and alanine in the small intestine, whilst apparent digestibility of the other AA was unaffected (Waghorn et al. $1987 b$ ). SAA were not measured. These findings suggest CT affects the apparent absorption of individual AA from the small intestine to different extents. It is important that the mechanisms by which CT affect the apparent absorption of AA from the small intestine are understood in order to maximize any potential nutritional benefits from including $\mathrm{CT}$ in ruminant diets.

Condensed tannin affected the metabolism of absorbed SAA by lowering the oxidation of methionine and cystine (Fig. 1) and increasing the rate of transulphuration of methionine to cystine. The latter is evident as increased flow from methionine to cystine in Fig. 1, and also as increased entry into the cystine pool (Fig. 1) from gut absorption/protein turnover, indicating that the increased methionine absorption from the small intestine induced by the action of CT was rapidly converted to cystine after absorption, probably in the liver (Radcliffe \& Egan, 1978). Reduction of cystine oxidation is further indicated by lower plasma taurine concentration in control sheep. Other reasons for the increased cystine utilization in body synthetic reactions (Fig. 1) when there was no increase in apparent cystine absorption from the small intestine due to CT (Table 3) could include problems of isotope recycling (due to the long infusion periods), and perhaps changes in endogenous protein secretion into the small intestine induced by CT. The net result of these changes was to increase plasma cystine flux to productive processes and maintenance by $110 \%$ compared with that for sheep given PEG. The increased cystine flux may indicate an increased net synthesis of wool proteins. Forages with CT have been associated with greater rates of $\mathrm{N}$ retention (Egan \& Ulyatt, 1980; John \& Lancashire, 1981; Waghorn et al. 
$1987 a, b)$ and leaner carcasses (Purchas \& Keogh, 1984) than comparable forages which did not contain CT. Also, increased wool growth has been demonstrated in sheep abomasally supplemented with methionine and cystine (Reis, 1979).

The $\mathrm{S}$ content of clean dry wool is $27-42 \mathrm{~g} / \mathrm{kg}$ (Reis $1965 \mathrm{a}, b$ ) and consists of twenty-six residues of cysteine for every one residue of methionine (Marshall \& Gillespie, 1977), suggesting wool growth is a productive process with a very high demand for cysteine. Therefore, the increased flux of cystine to productive processes and maintenance in control sheep could be expected to result in an increased rate of wool growth. It has recently been demonstrated that the wool growth of control sheep grazing sulla (Hedysarum coronarium) containing CT ( $48 \mathrm{~g} / \mathrm{kg} \mathrm{DM})$ was $12 \%$ higher than that of similar sheep grazing sulla but given a daily drench of PEG (Terrill et al. 1992).

The lower IRL of plasma sulphate in control sheep compared with PEG sheep is the result of a lower rate of oxidation of both methionine and cystine, and a lower rate of sulphate entry into plasma from sources other than the oxidation of SAA (Fig. 1). The lower sulphate entry rate into plasma in control sheep was probably a direct effect of a lower absorption of sulphide from the rumen (Expt 2), which is the main source of sulphate entry into plasma (Kennedy et al. 1975; Kennedy \& Milligan, 1978).

The presence of CT in forage diets would appear to provide one practical means of increasing SAA absorption from the small intestine, and of increasing the flux of cystine to productive processes and maintenance. It has been well documented that increasing the dietary CT concentration from 5 to $95 \mathrm{~g} \mathrm{CT} / \mathrm{kg}$ DM increases NAN flow to the small intestine in sheep fed on Lotus species (Barry et al. 1986; Waghorn et al. 1989). However, in control sheep fed on Lotus corniculatus (22 g CT/kg DM) Waghorn et al. (1987a) demonstrated a greater increase $(62 \%)$ in EAA absorption from the small intestine than was reported for methionine $(27 \%)$ and cystine $(4.5 \%)$ in control sheep fed on Lotus pedunculatus $(55 \mathrm{~g} \mathrm{CT} / \mathrm{kg} \mathrm{DM})$ in the present study. Therefore, further research is necessary to define better the relationship between CT concentration in the diet, absorption from the small intestine and changes in plasma SAA metabolism, particularly at lower CT concentrations, as it may be possible to improve further the flux of cystine to productive processes and maintenance. The dietary concentration of CT needed to maximize these processes needs to be defined.

The authors wish to thank Dr R. Patchell, and Mr H. Voon of the Poultry Research Centre (now Monogastric Research Centre), Massey University, Palmerston North, New Zealand for their help with the HPLC, Dr M. Hedley and colleagues in the Fertiliser and Lime Research Centre (Massey University) for their help with the sulphate analysis, Dr R. Tillman (Soil Science, Massey University) for his help with scintillation counting and Miss R. A. Watson (Department of Animal Science, Massey University) for skilled technical assistance.

\section{REFERENCES}

Ashes, J. R., Mangan, J. L. \& Sidhu, G. S. (1984). Nutritional availability of amino acids from protein crosslinked to protect against degradation in the rumen. British Journal of Nutrition 52, 239-246.

Barry, T. N. (1981). Protein metabolism in growing lambs fed on fresh ryegrass (Lolium perenne) white-clover (Trifolium repens) pasture ad lib. British Journal of Nutrition 46, 521-532.

Barry, T. N. (1989). Condensed tannins: Their role in ruminant protein and carbohydrate digestion and possible effects upon the rumen ecosystem. In The Roles of Protozod and Fungi in Ruminant Digestion, pp. 153-167 [J. V. Nolan, R. A. Leng and D. I. Demeyer, editors]. Australia: University of New England Publishing Unit

Barry, T. N \& Forss, D. A. (1983). The condensed tannin content of vegetative Lotus pedunculatus, its regulation by fertiliser application, and effect upon protein solubility. Journal of the Science of Food and Agriculture 34, 1047-1056.

Barry, T. N. \& Manley, T. R. (1986). Interrelationships between the concentrations of total condensed tannin, free 
condensed tannin and lignin in Lotus sp. and their possible consequences in ruminant nutrition. Journal of the Science of Food and Agriculture 37, 248-254.

Barry, T. N., Manley, T. R. \& Duncan, S. J. (1986). The role of condensed tannins in the nutritional value of Lotus pedunculatus for sheep. 4. Sites of carbohydrate and protein digestion as influenced by dietary reactive tannin concentration. British Journal of Nutrition 55, 123-137.

Beever, D. E. \& Siddons, R. C. (1986). Digestion and metabolism in the grazing ruminant. In Control of Digestion and Metabolism in Ruminants, pp. 479-496 [L. P. Milligan, W. L. Grovum and A. Dobson, editors]. New Jersey: Prentice Hall.

Binnerts, W. T., van't Klooster, A. Th. \& Frens, A. M. (1968). Soluble chromium indicator measured by atomic absorption in digestion experiments. Veterinary Record 82, $470-476$.

Egan, A. R. \& Ulyatt, M. J. (1980). Quantitative digestion of fresh herbage by sheep. 1. Utilization of nitrogen in five herbages. Journal of Agricultural Science, Cambridge 94, 47-56.

Faichney, G. J. (1975). The use of markers to partition digestion within the gastro-intestinal tract of ruminants. In Digestion and Metabolism in the Ruminant, pp. 227-291 [I. W. McDonald and A. C. I. Warner, editors]. Australia: University of New England Publishing Unit.

Ferguson, K. A., Hemsley, J. A. \& Reis, P. J. (1967). Nutrition and wool growth. The effect of protecting dietary protein from microbial degradation in the rumen. Australian Journal of Science 30, 215-217.

Flores, J. F., Stobbs, T. H. \& Minson, D. J. (1979). The influence of the legume Leucaena leucocephala and formaldehyde-treated casein on the production and composition of milk from grazing cows. Journal of Agricultural Science, Cambridge 92, 351-360.

Hungate, R. E. (1966). The rumen and its microbes. London: Academic Press.

John, A. \& Lancashire. J. A. (1981). Aspects of the feeding and nutritive value of Lotus species. Proceedings of the New Zealand Grasslands Association 42, 152-159.

Johnson, C. M. \& Nishita, H (1952). Microestimation of sulfur in plant materials, soils, and irrigation waters. Analytical Chemistry 24, 736-742.

Jones, W. T. \& Mangan, J. L. (1977). Complexes of the condensed tannins of sainfoin (Onobrychis vicilfolia Scop.) with Fraction 1 Leaf protein and with submaxillary mucoprotein, and their reversal by polyethylene glycol and $\mathrm{pH}$. Journal of the Science of Food and Agriculture 28, 126-136.

Kennedy, P. M. \& Milligan, L. P. (1978). Quantitative aspects of the transformation of sulphur in sheep. British Joumal of Nutrition 39, 65-72.

Kennedy, P. M., Williams, E. R. \& Siebert, B. D. (1975). Sulphate recycling and metabolism in sheep and cattle. Australian Joumal of Biological Science $28,31-42$.

Lee, J. (1983). Evaluation of the inductively coupled organ plasma emission spectrometer during 'bedding-in ' and its performance in the analysis of biological materials. Technical Report no. 3. Palmerston North, New Zealand: Applied Biochemistry Division, DSIR.

MacRae, J. C. \& Ulyatt, M. J. (1974). Quantitative digestion of fresh herbage by sheep. II. The sites of digestion of some nitrogenous constituents. Journal of Agricultural Science, Cambridge 82, 309-319.

Marshall, R. C. \& Gillespie, J. M. (1977). The keratin proteins from wool, horn and hoof from sheep. Australian Journal of Biological Sciences 30, 389-397.

Mathers, J. C. \& Miller, E. L. (1980). A simple procedure using ${ }^{35} \mathrm{~S}$ incorporation for the measurement of microbial and undegraded food protein in ruminant digesta. British Journal of Nutrition 43, 503-518.

Nolan, J. V., Norton, B. W. \& Leng, R. A. (1976). Further studies of the dynamics of nitrogen metabolism in sheep. British Journal of Nurtition 35, 127-133.

Purchas, R. W. \& Keogh, R. G. (1984). Fatness of lambs on Grasslands 'Maku' Lotus and Grasslands 'Huia' white clover. Proceedings of the New Zealand Society of Animal Production 44, 219-222.

Radcliffe, B. C. \& Egan, A. R. (1978). The effect of diet and of methionine loading on activity of enzymes in the transulphuration pathway in sheep. Australian Journal of Biological Sciences 31, 105-107.

Reis, P. J. (1965a). Variation in the sulphur content of wool. In Biology of the Skin and Hair Growth, pp. 365-379 [A. G. Lyne and B. F. Short, editors]. Sydney: Angus and Robertson.

Reis, P. J. (1965b). The growth and composition of wool. III. Variation in the sulphur content of wool. Australian Journal of Biological Sciences 18, 671-679.

Reis, P. J. (1979). Effects of amino acids on the growth and properties of wool. In Physiological and Environmental Limitations to Wool Growth, pp. 223-242 [J. L. Black and P. J. Reis, editors]. Australia: University of New England Publishing Unit.

Reis, P. J. \& Schinckel, P. G. (1963). Some effects of sulphur-containing amino acids on the growth and composition of wool. Australian Journal of Biological Sciences 16, 218-230.

Rogers, G. L., Bryant, A. M. \& McLeay, L. M. (1979). Silage and dairy cow production. III. Abomasal infusions of casein, methionine, and glucose, and milk yield and composition. New Zealand Journal of Agricultural Research 22, 533-541.

Stobbs, T. H., Minson, D. J. \& McLeod, M. N. (1977). The response of dairy cows grazing a nitrogen fertilized grass pasture to a supplement of protected casein. Journal of Agricultural Science, Cambridge 89, 137-141.

Tan, T. N., Weston, R. H. \& Hogan, J. P. (1971). Use of ${ }^{103}$ Ru-labelled tris (1,10-phenanthroline) ruthenium (II) chloride as a marker in digestion studies with sheep. International Journal of Applied Radiation and Isotopes $\mathbf{2 2}$, $301-308$. 
Terrill, T. H., Douglas, G. B., Foote, A. G., Purchas, R. W., Wilson, G. F. \& Barry, T. N. (1992). Effect of condensed tannins upon body growth, wool growth and rumen metabolism in sheep grazing sulla and perennial pasture. Journal of Agricultural Science, Cambridge 119, 265-273.

Waghorn, G. C., John, A., Jones, W. T. and Shelton, I. D. (1987a). Nutritive value of Lotus corniculatus L. containing low and medium concentrations of condensed tannins for sheep. Proceedings of the New Zealand Society of Animal Production 47, 25-30.

Waghorn, G. C., Jones, W. T., Shelton, I. D. \& McNabb, W. C. (1989). Condensed tannins and the nutritive value of herbage. Proceedings of the New Zealand Grasslands Association 51, 171-179.

Waghorn, G. C., Ulyatt, M. J., John, A. \& Fisher, M. T. (1987 b). The effect of condensed tannins on the site of digestion of amino acids and other nutrients in sheep fed on Lotus corniculatus L. British Journal of Nutrition 57, $115-126$.

Williams, C. H. \& Twine, J. R. (1967). Determination of nitrogen, sulphur, phosphorus, potassium, sodium, calcium and magnesium in plant materials by automatic analysis. In CSIRO Technical Paper no. 24, pp. 119. Melbourne: CSIRO. 